\title{
Epidemiology and screening for autistic pathology in Nghe An province, Vietnam
}

\author{
S.C. Thuc ${ }^{1}$, K.A.T. Thi ${ }^{2}$, L.T. Ngoc $^{3}$ and H.D. Vinh ${ }^{2}$ \\ ${ }^{1}$ Nghe An Pediatric Hospital \\ ${ }^{2}$ Vinh Medical University and Vinh Medical University Hospital \\ ${ }^{3}$ University of Medicine Pham Ngoc Thach \\ Corresponding author: H.D. Vinh \\ E-mail: hiepdv@pnt.edu.vn
}

Genet. Mol. Res. 20 (1): gmr18738

Received December 30, 2019

Accepted April 20, 2020

Final Revision January 25, 2021

Published April 30, 2021

DOI http://dx.doi.org/10.4238/gmr18738

\begin{abstract}
Autism spectrum disorder (A S D) in children is on the rise and is a concern for parents and the community. There has been no research on the epidemiology of autism in children in general and children under six years old in particular in Nghe An, Vietnam. We examined the prevalence of ASD among children under 6 years of age in this region. We retrospectively studied the medical records of perinatal centers and children's outpatient clinics and hospitals. A relationship was found between cases of autism and risk factors, including congenital asphyxia, sepsis during pregnancy, multiple pregnancies, late reproductive age of the mother, children's watching television time, and parents' spending less time with children.
\end{abstract}

Key words: Autism spectrum disorder; Vietnam; Evidence- based medicine; Early diagnosis

\section{INTRODUCTION}

Autism spectrum disorders are defined as developmental defects that can be characterized as a lack of initiation and maintenance of relationship with society, limitation of the range of interests, and stereotypical repetition of behavioral manifestations (American Psychiatric Association, 2013). Manifestation of ASD 
typically begins in childhood, with subsequent persistence throughout later life (World Health Organization, 2019).

\section{Prevalence}

Multiple manifestations of autism occur in over 50 million of the world's population (Baxter et al., 2015). According to prevalence data, an average of 1 in 59 children has ASD. (Baio, 2018; Centers for Disease Control, 2020). Nevertheless, there is a tendency towards stabilization of the number of patients with ASD (Xu et al., 2018). Geographically, ASD dominates in East Asia, where the is about 0.51\%, which is significantly higher than in Western $(0.35 \%)$ and South Asia $(0.31 \%)$. (Qiu et al., 2020). In South Korea, the total prevalence was 10.97 per 100,000 in 2015 (Hong et al., 2020). A significantly larger number of cases of ASD is recorded among the urban population, where the prevalence is $1.238 \%$, while among urban residents, it is $0.580 \%$ (Hoang et al., 2019). ASD is significantly more common in boys (Loomes et al., 2017). Girls with ASD still have relatively retained communicative abilities; girls are more sociable than boys with ASD (Ros-Demarize et al., 2020).

\section{Risk factors}

Diagnostic measures for ASD are mainly associated with the detection of behavioral symptom complexes during physical examination, despite the genetic and neurobiological studies of this pathology. (Hyman et al., 2020). ASD is a multifactorial disease caused by various modifiable and unmodifiable risk factors (Park et al., 2016). All factors that lead to ASD development can be divided into three groups: genetic, maternal health, and neurological (Elsabbagh, 2020).

The causation of ASD by genetic predictors is about 50\% (Sandin et al., 2014). Studies conducted on twins and probands have shown a high role of genetic and nongenetic factors in predisposition to ASD (Tick et al., 2016). Hereditary predisposition to ASD is due to changes in brain development under the influence of genetic factors (Nakagawa et al., 2019).

Non-modifiable factors that influence the development of ASD in the prenatal period include fertile age over 35 years, racial predisposition (white and Asian races), gestational diabetes and hypertension, the presence of prenatal bleeding and the threat of termination of pregnancy. Perinatal risk factors include a significant number of previous pregnancies (more than 4), breech presentation of the fetus, caesarean section, preeclampsia. In the postpartum period, among the risk factors for ASD are low birth weight, the presence of postpartum hemorrhage, and the male gender of the newborn. (Wang et al., 2017; Lukmanji et al., 2019). Sensitizing the immune response of a pregnant woman is also implicated in ASD and increases susceptibility to autism (Solek et al., 2018; Brown and Conway, 2019). Neonatal jaundice was associated with ASD at 35-37 weeks $(\mathrm{aOR}=1.83,95 \% \mathrm{CI}$ 105-319), but not $\geq 38$ weeks gestation $(\mathrm{aOR}=0.97,95 \%$ CI $0.76-1.24)$ (Cordero et al., 2020). 
To better understand autism in Vietnam, we examined its incidence in various regions of the country in young children.

\section{MATERIAL AND METHODS}

A prevalence study was made of 14,000 children, 12-72 months old, in Nghe An involving seven districts in four geographic regions including: Vinh city, Dien Chau, Quynh Luu, Tan Ky, Thanh Chuong, Nghia Dan, and Quy Chau. We retrospectively studied the medical records of perinatal centers and children's outpatient clinics and hospitals. The data were analyzed using statistical methods (packages SPSS version 22, EZR version 1.38 (Saitama Medical Center, Jichi Medical University. To present the typical result for nominal qualitative variables, the mode of indicators, interval estimation of dichotomous variables) were used. When making multiple comparisons between groups, we used the Chi-square test with Bonferroni correction.

Inclusion criteria: children aged 12-72 months, signed voluntary agreement of parents for the participation of children in the study. Exclusion criteria: presence of congenital organic pathology (heart defects, central and peripheral nervous system, hemoblastosis). The study design and informed consent form were reviewed and approved by the institutional expert bioethics committee and the parents or responsible guardians signed informed consent forms.

\section{RESULTS}

The autism rate is $1.57 \%$. The rate of mild and moderate autism was $0.88 \%$. The frequency of severe autistism was $0.69 \%$ (Table 1 ).

Table 1. Prevalence of autism in the children aged 12-72 months in Vietnam.

\begin{tabular}{|c|c|c|c|c|c|c|c|c|}
\hline \multirow[t]{2}{*}{ Location } & \multirow[t]{2}{*}{ n } & \multirow{2}{*}{$\begin{array}{l}\text { Average } \\
\text { age in } \\
\text { years }\end{array}$} & \multicolumn{2}{|l|}{ Male } & \multicolumn{2}{|c|}{ Female } & \multicolumn{2}{|c|}{$\begin{array}{l}\text { Number autistic of } \\
\text { children }\end{array}$} \\
\hline & & & $\mathbf{n}$ & $\%$ & $\mathbf{n}$ & $\%$ & male & female \\
\hline Vinh & 3000 & $3.34 \pm 1.1$ & 1664 & 55.0 & 1336 & 44.4 & 72 & 15 \\
\hline Dien Chau & 3000 & $3.49 \pm 1.4$ & 1620 & 54.0 & 1380 & 46.0 & 16 & 7 \\
\hline Quynh Luu & 3000 & $3.93 \pm 1.6$ & 1885 & 62.8 & 1115 & 37.2 & 22 & 7 \\
\hline Nghia Dan & 1500 & $3.96 \pm 1.1$ & 866 & 57.7 & 634 & 42.3 & 16 & 9 \\
\hline Thanh Chuong & 1500 & $3.92 \pm 1.6$ & 802 & 53.5 & 698 & 46.7 & 12 & 5 \\
\hline Tan Ky & 1500 & $3.68 \pm 1.1$ & 778 & 51.8 & 722 & 48.2 & 12 & 7 \\
\hline Quy Chau & 500 & $3.51 \pm 1.1$ & 314 & 62.8 & 186 & 37.2 & 12 & 8 \\
\hline Total & 14000 & $3.69 \pm 1.3$ & 7929 & 56.7 & 6071 & 43.3 & 162 & 58 \\
\hline $\begin{array}{l}\text { Significance } \\
\text { level of } \\
\text { difference in } \\
\text { the prevalence } \\
\text { of autism } \\
\text { between } \\
\text { groups, } \mathrm{P}\end{array}$ & $<0.001$ & & & & & & & \\
\hline
\end{tabular}

The incidence of the disease in males $>$ females $(73.6 \%$ male, $26.4 \%$ female). The children with age from 2-3 years old accounted for $42 \%$. 
Table 2. The proportion of autistic children by age.

\begin{tabular}{|c|c|c|c|c|c|c|}
\hline Age & $\mathbf{n}$ & $\%$ & \multicolumn{2}{|l|}{ Male } & \multicolumn{2}{|c|}{ Female } \\
\hline $1-<2$ years old & 37 & 16.8 & 31 & 83.7 & 6 & 16.3 \\
\hline $2-<3$ years old & 74 & 33.6 & 65 & 87.8 & 9 & 12.2 \\
\hline $3-<4$ years old & 47 & 21.4 & 34 & 72.3 & 13 & 17.7 \\
\hline $4-<5$ years old & 45 & 20.5 & 25 & 55.6 & 20 & 44.4 \\
\hline $5-\leq 6$ years old & 17 & 7.7 & 7 & 41.2 & 10 & 58.8 \\
\hline Total & 220 & 100 & 162 & 73.6 & 58 & 26.4 \\
\hline \multicolumn{7}{|l|}{ p (year old) } \\
\hline \multicolumn{7}{|c|}{$\begin{array}{l}\text { Significance level of difference }<0.001 \\
\text { in the prevalence of autism } \\
\text { between groups, } \mathrm{P}\end{array}$} \\
\hline
\end{tabular}

ASD detected in city area- 87 children or $39.5 \%$ of all cases. Quantity of moderate and severe autism was $123: 97$ cases (55\%:45\%). Proportion of moderate and severe autism by gender was $78.4 \%$ male to $21.6 \%$ in females. Among ASD risk factors, the following were detected. We compared them between different forms of ASD. (Table 3)

Table 3. Comparison of risk factors between mild, moderate and severe autistic children.

\begin{tabular}{|c|c|c|c|c|c|c|}
\hline \multirow[t]{2}{*}{ No. } & \multirow[t]{2}{*}{ Prehistoric maternity } & \multirow[t]{2}{*}{ Total } & \multicolumn{2}{|c|}{ Mild and moderate } & \multirow{2}{*}{$\begin{array}{l}\text { Severe } \\
\text { n \% }\end{array}$} & \multirow[t]{2}{*}{$\mathbf{P}$} \\
\hline & & & n & $\%$ & & \\
\hline 1 & Normal birth & 167 & 108 & 64.7 & 5935.3 & $<0.001$ \\
\hline 2 & Asphyxiation & 12 & 4 & 25.0 & 875.0 & 0.014 \\
\hline 3 & Premature birth & 4 & 1 & 25.0 & 375.0 & $(-)$ \\
\hline 4 & Sepsis in pregnancy & 13 & 4 & 30.8 & 969.2 & 0.049 \\
\hline 5 & Elderly mother & 5 & 1 & 20.0 & 480.0 & $(-)$ \\
\hline 6 & Obstetric intervention & 8 & 2 & 25.0 & 675.0 & $(-)$ \\
\hline 7 & Twins & 2 & 0 & 0 & 2100 & $(-)$ \\
\hline \multirow[t]{2}{*}{8} & Newborn jaundice & 9 & 3 & 33.3 & 566.7 & $(-)$ \\
\hline & Total & 220 & 123 & 55.9 & 9744.1 & \\
\hline
\end{tabular}

Average time of TV viewing for children with mild and moderate ASD was $1.76 \pm 0.98$; for children with severe ASD it was $2.5 \pm 0.95$ hours per day $(\mathrm{t}=5.636, \mathrm{p}<$ 0.001). Average time parents were playing with their children was $1.91 \pm 0.96$ $\mathrm{h}$ o u r s pe $\mathrm{r}$ day for children with mild and moderate autism and $1.58 \pm 0.75$ for children with severe ASD $(\mathrm{t}=2.781, \mathrm{p}<0.0059)$. Among children with mild and moderate autism, $69(56.1 \%)$ were educated in kindergarten and $54(43.9 \%)$ were educated at home. Among children with severe autism $65(67 \%)$ were educated in kindergarten and $32(33 \%)$ at home.

These risk factors for autistic include pregnancy history, children's watching television time, parents spend less time with children. The parents' attending treatment or education for autism or normal is very important, promoting children's success. The level of Autism assesses Childhood Autism Rating Scale (CARS) (Randall et al., 2018). Related with the linear regression, pregnancy history, watching television time and the time playing with children of parents (Table 4). 
Table 4. Multivariate regression analysis of factors related to the degree of autism through the CARS (Childhood Autism Rating Scale) scale.

\begin{tabular}{|c|c|c|c|c|}
\hline Variable & Linear coefficients & Standard deviations & $\mathbf{t}$ & $\mathbf{P}$ \\
\hline Constant & 372.078 & & & \\
\hline Gender & -16.044 & 0.6667 & -2.407 & 0.0169 \\
\hline Prehistoric maternity & 19.131 & 0.6968 & 2.746 & 0.0066 \\
\hline Time watching television & 11.930 & 0.2919 & 4.086 & 0.0001 \\
\hline \multicolumn{5}{|c|}{ Multivariate correlation: $r=0.3654 \mathrm{R} 2=0.1335$} \\
\hline
\end{tabular}

Parents time to play with children was related to the level of severe autism, based on multivariate correlation equation $\mathrm{Y}=45.4967-0.4996$ the time playing with children. With $\mathrm{P}<0.05$. In which $\mathrm{Y}=$ total marks based on CARS scale (Siller et al., 2014).

\section{DISCUSSION}

We examined the prevalence of ASD among children under 6 years of age in Nghe An (Vietnam). Early identification of ASD allows the possibility of early intervention (Zwaigenbaum et al., 2015a). Mass introduction of screening with the introduction of data into medical records will help to improve the efficiency of early diagnosis of ASD (Lipkin and Macias, 2020). Screening tools are designed to help caregivers identify and report symptoms observed in children at high risk for ASD. The screens are based on early manifestations of symptoms of core deficits related to social communication. Some of these early symptoms that may alert the provider to the risk for ASD have been called "red flags" (Hyman et al., 2020).

Screening is not the gold standard for diagnosis, but it is important for the additional assessment of ASD. Screening methods are able to determine problems in the behavioral, speech and motor development of a child of 9, 18 and 30 months (Zwaigenbaum et al., 2015b).

The M-CHAT is the most studied and widely used tool for screening toddlers (mostly for children between 12-30 months) for ASD (Zwaigenbaum et al., 2015b; Hyman et al., 2020). Screening for ASD is not mandatory now and is not included in the universal guidelines for pediatrics (Hyman et al., 2020).

Irregular and brief check-ups can hide ASD symptoms even from an experienced doctor (Gabrielsen et al., 2015). The use of survey questionnaires is important in diagnosing ASD, especially the use of the Child Behavior Checklist or the Childhood Autism Assessment Scale. (Havdahl et al., 2016; Samms-Vaughan et al., 2017).

Evaluation of Co-occurring Developmental Conditions consist of: cognitive testing, language testing, adaptive function testing, motor assessment, a nd sensory assessment (hearing, vision, sensory processing).

\section{Intervention}

We found a significant relationship between cases of autism and children's watching television time; as a result, parents spend less time with children. 
The goals of treating children with autism is to compensate for behavioral and communication deficits (Wong et al., 2015).

Interventions for children with ASD are provided through education, developmental therapy, and behavioral intervention. Treatment strategies can vary according to the age and abilities of the child. Families should participate in the choice of intervention options and stay involved in educational and therapeutic decisions (Hyman et al., 2020).

Having a child with ASD makes a significant difference in the life of the family. Thus, more than $50 \%$ of the families surveyed reported the need to change the work schedule due to the need for enhanced care for a child with autism. (Clifford and Minnes, 2013). Parental awareness of ASD significantly improves the quality of care for a child with autism (Siller et al., 2014).

\section{CONCLUSIONS}

A significant relationship was found between cases of autism and risk factors such as congenital asphyxia, sepsis during pregnancy, multiple pregnancies, late reproductive age of the mother, children's watching television time, parents spend less time with children. Autism significantly predominates in males. The onset of autism is most common in children aged 24-36 months.

The detection and organization of treatment and teaching of children are necessary in order to create conditions for child personality development, social integration, and reduce the burden for the patient, the family, and society. Increasing family awareness and understanding of the medical home can promote partnership of the parents and primary care provider in planning and coordinating the child's care and advocating for their needs. Our government needs to develop services to promote social skills appropriate for work and postsecondary education, access to appropriate medical and behavioral health services, job skills development, and community leisure opportunities.

\section{ACKNOWLEDGMENTS} research.

The authors are thankful to Nghe An Pediatric Hospital for the support of the

\section{CONFLICTS OF INTEREST}

The authors declare no conflict of interest.

\section{REFERENCES}

Ameis SH, Kassee C, Corbett-Dick P, Cole L, et al. (2018). Systematic review and guide to management of core and psychiatric symptoms in youth with autism. Acta Psychiatr. Scand. 138(5): 379-400.

American Psychiatric Association (2013). Diagnostic and statistical manual ofmental disorders. 5th ed. Arlington, VA.

Baio J, Wiggins L, Christensen DL, Maenner MJ, et al. (2018). Prevalence of Autism Spectrum Disorder Among Children Aged 8 Years - Autism and Developmental Disabilities Monitoring Network, 11 Sites, United States, 2014. Morb. Mort. Week. Rep. Surv. Summ. (Washington D.C.), 67(6): 1-23. DOI:10.15585/mmwr.ss6706a1.

Baxter AJ, Brugha TS, Erskine HE, Scheurer RW, et al. (2015). The epidemiology and global burden of autism spectrum disorders. Psychol. Med. 45(3): 601-613. DOI:10.1017/S003329171400172X. 
Brown AS and Conway F (2019). Maternal immune activation and related factors in the risk of offspring psychiatric disorders. Front. Psychiatr. 10: 430. DOI:10.3389/fpsyt.2019.00430.

Centers for Disease Control and Prevention (2020). Data and Statistics on Autism Spectrum Disorder. Retrieved from https://www.cdc.gov/ncbddd/autism/data.html (accessed 5 October 2020).

Clifford T and Minnes P (2013). Who participates in support groups for parents of children with autism spectrum disorders? The role of beliefs and coping style. J. Autism Dev. Disord. 43(1): 179-187.

Cordero C, Schieve LA, Croen LA, Engel SM, et al. (2020). Neonatal jaundice in association with autism spectrum disorder and developmental disorder. J. Perinatol. 40(2): 219-225. DOI:10.1038/s41372-019-0452-4.

Elsabbagh M (2020). Linking risk factors and outcomes in autism spectrum disorder: is there evidence for resilience? $B M J: 16880$. DOI:10.1136/bmj.16880

Gabrielsen TP, Farley M, Speer L, Villalobos M, et al. (2015). Identifying autism in a brief observation. Pediatrics. 135(2): e330-e338. DOI:10.1542/peds.2014-1428.

Havdahl KA, von Tetzchner S, Huerta M, Lord C, et al. (2016). Utility of the child behavior checklist as a screener for autism spectrum disorder. Autism Res. 9(1): 33-42. DOI:10.1002/aur.1515.

Hoang VM, Le TV, Chu TTQ, Le BN, et al. (2019). Prevalence of autism spectrum disorders and their relation to selected socio-demographic factors among children aged 18-30 months in Northern Vietnam, 2017. Int. J. Ment. Health Syst. 13: 29. DOI: 10.1186/s13033-019-0285-8.

Hong M, Lee SM, Park S, Yoon SJ, et al. (2020). Prevalence and Economic Burden of Autism Spectrum Disorder in South Korea Using National Health Insurance Data from 2008 to 2015. J. Autism Dev. Disord. 50(1): 333-339. DOi: 10.1007/s10803-019-04255-y.

Hyman SL, Levy SE and Myers SM (2020). Identification, evaluation, and management of children with autism spectrum disorder. Pediatrics. 145(1): e20193447. DOI:10.1542/peds.2019-3447.

Lipkin PH and Macias MM (2020). Promoting optimal development: identifying infants and young children with developmental disorders through developmental surveillance and screening. Pediatrics. 145(1): e20193449. DOI:10.1542/peds.2019-3449.

Loomes R, Hull L and Mandy WPL (2017). What is the male-to-female ratio in autism spectrum disorder? A systematic review and meta-analysis. J. Am. Acad. Child Adolesc. Psychiatr. 56(6): 466-474. DOI: 10.1016/j.jaac.2017.03.013.

Lukmanji S, Manji SA, Kadhim S, Sauro KM, et al. (2019). The co-occurrence of epilepsy and autism: A systematic review. Epil. Behav. 98: 238-248. DOI: 10.1016/j.yebeh.2019.07.037.

Nakagawa N, Plestant C, Yabuno-Nakagawa K, Li J, et al. (2019). Memol-mediated tiling of radial glial cells facilitates cerebral cortical development. Neuron. 103(5): 836-852. DOI: 10.1016/j.neuron.2019.05.049.

Park HR, Lee JM, Moon HE, Lee DS, et al. (2016). A Short Review on the Current Understanding of Autism Spectrum Disorders. Exp. Neurobiol. 25(1): 1-13. DOI:10.5607/en.2016.25.1.1.

Qiu S, Lu Y, Li Y, Shi J, et al. (2020). Prevalence of autism spectrum disorder in Asia: A systematic review and metaanalysis. Psychiatr. Res. 284: 112679. DOI: 10.1016/j.psychres.2019.1126.

Randall M, Egberts K, Samtani A, et al. (2018). Diagnostic tests for autism spectrum disorder (ASD) in preschool children (Review). Cochrane Database of Systematic Reviews. 13-21.

Ros-Demarize R, Bradley C, Kanne SM, Warren Z, et al. (2020). ASD symptoms in toddlers and preschoolers: An examination of sex differences. Autism Res. 13(1): 157-166. DOI:10.1002/aur.2241.

Samms-Vaughan M, Rahbar MH, Dickerson AS, Loveland KA, et al. (2017). The diagnosis of autism and autism spectrum disorder in low- and middle-income countries: Experience from Jamaica. Autism Int. J. Res. Pract. 21(5):564-572. DOI:10.1177/1362361317698938.

Sandin S, Lichtenstein P, Kuja-Halkola R, Larsson H, et al. (2014). The familial risk of autism. JAMA. 311(17): 17701777. DOI:10.1001/jama.2014.4144.

Siller M, Reyes N, Hotez E, Hutman T, et al. (2014). Longitudinal change in the use of services in autism spectrum disorder: Understanding the role of child characteristics, family demographics, and parent cognitions. Autism. 18(4): 433-446.

Solek CM, Farooqi N, Verly M, Lim TK, et al. (2018). Maternal immune activation in neurodevelopmental disorders. Dev. Dyn. 247: 588-619. DOI:10.1002/dvdy.24612.

Tick B, Bolton P, Happé F, Rutter M, et al. (2016). Heritability of autism spectrum disorders: a meta-analysis of twin studies. J. Child Psychol. Psychiatr. 57: 585-595. DOI:10.1111/jcpp.12499.

Wang C, Geng H, Liu W and Zhang G (2017). Prenatal, perinatal, and postnatal factors associated with autism: A metaanalysis. Medicine. 96(18): e6696. DOI:10.1097/MD.0000000000006696.

Wong C, Odom SL, Hume KA, Cox AW, et al. (2015). Evidence-based practices for children, youth, and young adults with autism spectrum disorder: A comprehensive review. J. Autism Dev. Disord. 45(7): 1951-1966. DOI:10.1007/s10803-014-2351-z.

World Health Organization. (2019). Autism spectrum disorders. Retrieved from http:/www.who.int/mediacentre/factsheets/autism-spectrum-disorders/en/.

Xu G, Strathearn L, Liu B, Yang B, et al. (2018). Twenty-year trends in diagnosed attention-deficit/hyperactivity disorder among US children and adolescents, 1997-2016. JAMA Netw. Open. 1(4): e181471-e181471. DOI:10.1001/jama.2017.17812.

Genetics and Molecular Research 20 (1): gmr18738 
Zwaigenbaum L, Bauman ML, Choueiri R, Kasari C, et al. (2015a). Early intervention for children with autism spectrum disorder under 3 years of age: recommendations for practice and research. Pediatrics. 136 (Suppl. 1): 60-81. DOI:10.1542/peds.2014-3667E.

Zwaigenbaum L, Bauman ML, Fein D, Pierce K, et al. (2015b). Early screening of autism spectrum disorder: Recommendations for practice and research. Pediatrics. 136: 41-59. DOI:10.1542/peds.2014-3667D. 